\title{
IDENTIFIKASI MISKONSEPSI SISWA TERHADAP KONSEP-KONSEP IPA BIOLOGI SEKOLAH DASAR
}

\author{
Imas Srinana Wardani \\ Universitas PGRI Adibuana Surabaya \\ imassrinanawardani@ rocketmail.com
}

\begin{abstract}
ABSTRAK
Tujuan penelitian ini adalah untuk mengidentifikasi profil jenis kesalahan konsep pada siswa, karena salah satu faktor kesalahan dalam pembelajaran IPA adalah terjadinya miskonsepsi yang berasal dari siswa sendiri (konsepsi awal sebelum pelajaran, pengalaman, kemampuan, dan minat), dari guru yang juga punya salah. Rendahnya mutu pendidikan IPA yang secara umum diterima oleh para pendidik IPA adalah adanya miskonsepsi dan kondisi pembelajaran yang kurang memperhatikan prakonsepsi yang dimiliki siswa pengertian dan salah mengajar, serta dari buku yang digunakan.

Penelitian dalam makalah ini adalah penelitian kualitatif. Subyek penelitian adalah siswa SD kelas V yang berada di wilayah Surabaya. Sekolah yang dipilih yaitu sekolah SDN 250 yang terletak di Sukolilo No. 31/32 Surabaya. Prosedur yang digunakan dalam penelitian ini adalah wawancara, inventarisasi konsep, mengembangkan butir tes, memberikan tes, mendeskripsikan konsep-konsep biologi, memetakan 34 butir soal yang diujikan berdasarkan SK dan KD.

Kata kunci: Identifikasi, konsep IPA Biologi.
\end{abstract}

\section{Pendahuluan}

Salah satu ciri pendidikan sains adalah bahwa sains lebih dari sekedar kumpulan yang dinamakan fakta, sains merupakan kumpulan pengetahuan dan juga kumpulan proses. Peraturan Menteri Pendidikan Nasional No. 22 Tahun 2006 menyatakan, pembelajaran IPA di Sekolah Dasar (SD) untuk menumbuhkan kemampuan berpikir, bekerja dan bersikap ilmiah.

Hasil penelitian menunjukkan sebagian besar siswa tidak berkembang dalam hal pemahaman konsep-konsep ilmiah dan prosesnya secara terintegrasi dan fleksibel. Sebagai contoh, mereka dapat menghafalkan berbagai konsep dan fakta, tetapi tidak dapat menggunakannya untuk menjelaskan fenomena dalam kehidupan yang berhubungan dengan konsep tersebut (Santa, 1991)

IPA hanya dipahami sebagai jalan untuk mendapatkan pengetahuan (kognitif) belum sampai pada pembentukan pola pikir apalagi budi pekerti, sehingga dalam pembelajaran IPA masih terdapat kesalahan.

Beberapa faktor penyebab terjadinya kesalahan dalam pembelajaran IPA di SD diantaranya yaitu berawal dari masalah bahwa anak yang masih berada pada tahap operasional konkrit sudah harus mempelajari konsep-konsep abstrak, belum optimalnya guru dalam mengelola pembelajaran terutama dalam meningkatkan penguasaan konsep. Menurut Sumaji (2003) salah satu faktor kesalahan dalam pembelajaran IPA adalah terjadinya miskonsepsi dalam 
pembelajaran IPA yang berasal dari siswa sendiri (konsepsi awal sebelum pelajaran, pengalaman, kemampuan, dan minat), dari guru yang juga punya salah pengertian dan salah mengajar, serta dari buku yang digunakan.

Sadia (dalam Nirahua, 2009) mengemukakan bahwa penyebab universal atas rendahnya mutu pendidikan IPA yang secara umum diterima oleh para pendidik IPA adalah adanya miskonsepsi dan kondisi pembelajaran yang kurang memperhatikan prakonsepsi yang dimiliki siswa. Ini ditunjukkan dengan terdapat banyak kesalahan dalam konsep siswa maupun guru.

Dalam beberapa bahan pustaka kesalahan dapat disebabkan oleh penguasaan konsep siswa belum lengkap, sederhana, berbeda (Kardi, 1999).

Berdasarkan kenyataan di atas, perlu diupayakan untuk mengetahui profil miskonsepsi siswa SD. Karena dengan meminimalkan kesalahan konsep berarti menghindari kendala-kendala pembelajaran yang mengarah pada terjadinya miskonsepsi sehingga tujuan pembelajaran lebih mudah dicapai.

Berdasarkan uraian latar belakang, peneliti mengambil judul "Identifikasi miskonsepsi siswa terhadap konsep-konsep IPA biologi sekolah dasar". Tujuan penelitian ini adalah untuk mengidentifikasi profil jenis kesalahan konsep pada siswa, sehingga diharapkan dapat digunakan sebagai acuan dalam memperbaiki pendekatan guru kepada siswa dalam memberikan pengalaman belajar sehingga tidak terjadi kesalahan konsep.

\section{METODE PENELITIAN}

Penelitian dalam makalah ini adalah penelitian kualitatif. Subyek penelitian adalah siswa SD kelas $\mathrm{V}$ yang berada di wilayah Surabaya. sekolah yang dipilih yaitu sekolah SDN 250 yang terletak di Sukolilo No. 31/32 Surabaya.

Berdasarkan hasil tes yang diujikan dan hasil wawancara pada mereka, dipilih lima orang siswa kelas V SD yang dijadikan sebagai subyek wawancara penelitian. Prosedur yang digunakan dalam penelitian ini adalah 1) Melakukan wawancara dengan guru SD kelas V Wawancara digunakan untuk mengetahui sejauh mana guru tersebut menyampaikan materi pelajaran di kelas $\mathrm{V}$ dan buku-buku yang digunakan sebagai acuan, 2) Melakukan inventarisasi konsep yang salah dari berbagai sumber seperti guru, siswa, dan buku-buku sumber yang digunakan di sekolah, 3) Mengembangkan butir tes untuk mengetahui apakah konsepkonsep yang salah tersebut juga terjadi pada siswa, 4) Memberikan tes. kepada siswa, yaitu berupa butir tes yang salah konsep yang sudah dikembangkan, 5) Mendeskripsikan konsep-konsep biologi yang mengalami salah konsep, 6) Memetakan 34 butir soal yang diujikan berdasarkan SK dan KD.

\section{HASIL PENELITIAN}

Dari data hasil penelitian di dua sekolah dengan menggunakan butir tes pilihan benar salah sebanyak 34 butir tes konsep IPA biologi, menunjukkan bahwa kesalahan konsep yang terjadi pada siswa SD kelas V relatif cukup tinggi bahkan persentase konsep yang teridentifikasi salah konsep sebesar $85 \%$. 
Kesalahan konsep terdapat pada konsep yang dijaring melalui butir tes nomer $1,2,3$, $4,5,6,8,9,10,11,12,13,14,15,16,17$, $19,20,21,22,23,26,27,29,30,31,32,33$, 34.

Tabel 1 Persentase Kesalahan Konsep pada Siswa SD Kelas V

\begin{tabular}{|c|c|c|}
\hline $\begin{array}{c}\text { Jumlah } \\
\text { Konsep } \\
\text { yang } \\
\text { Teridentifikasi }\end{array}$ & $\begin{array}{c}\text { Jumlah } \\
\text { Konsep } \\
\text { Salah } \\
\text { pada } \\
\text { Siswa }\end{array}$ & $\begin{array}{c}\text { Persentase } \\
\text { Kesalahan } \\
\text { Konsep }\end{array}$ \\
\hline 34 & 29 & $85 \%$ \\
\hline
\end{tabular}

Tabel 2 Persentase Siswa SD Kelas V yang Salah Konsep Per item Soal

\begin{tabular}{|c|c|c|}
\hline No & $\begin{array}{c}\text { Jumlah kesalahan } \\
\text { konsep }\end{array}$ & Persentase \\
\hline 1 & 16 & $72,7 \%$ \\
\hline 2 & 17 & $77,3 \%$ \\
\hline 3 & 13 & $59,1 \%$ \\
\hline 4 & 16 & $72,7 \%$ \\
\hline 5 & 17 & $77,2 \%$ \\
\hline 6 & 11 & $50 \%$ \\
\hline 7 & 5 & $22,7 \%$ \\
\hline 8 & 14 & $63,6 \%$ \\
\hline 9 & 17 & $77,3 \%$ \\
\hline 10 & 13 & $59,1 \%$ \\
\hline 11 & 12 & $54,6 \%$ \\
\hline 12 & 15 & $68,2 \%$ \\
\hline 13 & 8 & $36,4 \%$ \\
\hline 14 & 13 & $59,1 \%$ \\
\hline 15 & 19 & $86,4 \%$ \\
\hline
\end{tabular}

\begin{tabular}{|c|c|c|}
\hline 16 & 16 & $72,7 \%$ \\
\hline 17 & 18 & $81,8 \%$ \\
\hline 18 & 13 & $59,1 \%$ \\
\hline 19 & 11 & $50 \%$ \\
\hline 20 & 20 & $90,9 \%$ \\
\hline 21 & 16 & $72,7 \%$ \\
\hline 22 & 8 & $36,4 \%$ \\
\hline 23 & 12 & $54,6 \%$ \\
\hline 24 & 2 & $9,1 \%$ \\
\hline 25 & 6 & $27,3 \%$ \\
\hline 26 & 19 & $86,4 \%$ \\
\hline 27 & 15 & $68,2 \%$ \\
\hline 28 & 2 & $9,1 \%$ \\
\hline 29 & 15 & $68,2 \%$ \\
\hline 30 & 17 & $77,3 \%$ \\
\hline 31 & 10 & $45,5 \%$ \\
\hline 32 & 8 & $36,4 \%$ \\
\hline 33 & 14 & $63,6 \%$ \\
\hline 34 & 11 & $50 \%$ \\
\hline
\end{tabular}

Berdasarkan hasil diagnosis kesalahankesalahan siswa terhadap konsep-konsep IPA biologi, berikut ini disajikan rangkuman temuan dan tolak ukur hasil-hasil penelitian

Matriks Temuan dan Tolak Ukur HasilHasil Penelitian

Soal no: 1, 2, 3, 4, 5, 6, 8, 9, 10, 11, 12, 13, $14,15,16,17,19,20,21,22,23$, $26,27,29,30,31,32,33,34$

Temuan: Siswa salah dalam menuliskan jawaban. 
Tolak ukur

- Sebagian besar konsep yang diajarkan kepada siswa tidak benar-benar difahami siswa (Kardi,1997)

- konsep yang dipelajari siswa di sekolah tidak sama dengan konsepsi yang dipegang oleh para pakar sains (Berg, 1991).

Soal no: $1,2,8,9,11,12,13,14,15,17$, $21,23,26,27,29,30,32,33,34$

Temuan

- Siswa mengalami kesalahan konsep. Yaitu tidak menguasai konsep-konsep prasyarat materi pelajaran.

Tolak Ukur

- Siswa tidak menguasai konsep prasyarat, hal ini menyebabkan siswa mengalami miskonsepsi (Kardi,1997).

- Hasil penelitian Arnold dan Simpson (1980) menunjukkan bahwa karena tidak memahami konsep tentang benda hidup, gas, makanan, dan energi, siswa mengalami miskonsepsi mengenai konsep fotosintesis.

Soal no: 3, 4, 5, 6, 29,

Temuan:

Siswa mengalami kesalahan konsep. Yaitu siswa membentuk konsep dengan menggabungkan pengalaman yang sudah siswa pahami dengan pengalaman yang baru siswa alami.

Tolak Ukur:

- Tafsiran perorangan terhadap banyak konsep berbeda dari tafsiran guru atau buku (Berg,1991).
Soal no: 5, 6, 15, 19, 31.

Temuan

- Siswa mengalami kesalahan konsep. Yaitu siswa tidak bisa menghubungkan konsepnya dengan kehidupan seharihari.

Tolak Ukur

- Siswa tidak dapat menghubungkan konsep dengan kehidupan sehari-hari (Berg, 1991).

- Siswa membentuk konsep sesuai dengan

- pengalamannya sehari-hari (Sumaji: dkk.,2003).

Soal no: 8, 9, 21.

Temuan

- Siswa mengalami kesalahan konsep. Yaitu istilah-istilah dalam biologi.

Tolak Ukur

- Istilah-istilah yang tidak tepat dan penggunaannya yang tidak konsisten, tidak membantu siswa dalam pembelajaran konsep (Gilbert et al,1982).

Soal no: $9,10,11,12,13,14,15,16,22,26$, 27, 30, 31, 32, 33 .

Temuan

- Siswa mengalami kesalahan konsep. Yaitu siswa tidak bisa membedakan atribut penentu dari atribut umum.

Tolak ukur

- Hasil penelitian menunjukkan bahwa salah satu penyebab terjadinya miskonsepsi ialah ketidak mampuan siswa membedakan atribut penentu dari atribut umum (Kardi,1997). 
No soal: 20.

Temuan

- Siswa mengalami kesalahan konsep. Yaitu dalam mengajar, metode yang digunakan guru tidak menarik.

Tolak Ukur

- Penggunaan analogi dalam mengajarkan konsep adalah baik dan membantu memudahkan siswa menangkap konsep, tetapi kadang juga menimbulkan salah pengertian (Dupin dkk,.1987)

\section{PENUTUP}

\section{Simpulan}

Berdasarkan dengan tujuan yang ingin dicapai dalam penelitian, maka dirumuskan beberapa temuan-temuan yaitu, pada siswa SD kelas V khususnya SDN 250 Surabaya, terdapat miskonsepsi atau kesalahan konsep IPA biologi, hal ini dapat diketahui dari 34 butir soal (konsep), 85\% butir soal (konsep) dijawab salah dan hanya $15 \%$ butir soal (konsep) yang dijawab benar. Setelah dilakukan wawancara diketahui faktor-faktor yang mempengaruhi kesalahan konsep, yaitu siswa tidak menguasai konsep materi IPA biologi, terdapat kesalahan konsep pada buku teks yang digunakan siswa dan guru. Faktor yang berasal dari siswa sendiri, yaitu siswa tidak mampu menemukan atribut penentu, tidak menguasai konsep prasyarat, banyak kata-kata dan istilah yang tidak tepat, dan siswa memiliki penafsiran sendiri berdasarkan pengalaman yang siswa alami.

\section{DAFTAR PUSTAKA}

Berg, Enwe V.D. dkk. 1991. Miskonsepsi, Fisiska dan Remediasi, Salatiga: Universitas Kristen Staya Wacana.
Campbell, Neil A., Jane B Reece, Lawrence G.Mitchell. 2003. Biologi (2). Jakarta: Erlangga.

Campbell, Neil A., Jane B Reece, Lawrence G.Mitchell. 2004. Biologi (3). Jakarta: Erlangga

Hinduan, A. A. 2005. Meningkatkan profesionalisme guru IPA sekolah. Makalah Seminar Himpunan Sarjana Pendidikan Ilmu Pendidikan Alam Indonesia (HISPIPAI), Bandung tanggal 22-23 Juli 2005.

Kardi, Soeparman. 1997. Miskonsepsi Terhadap Konsep-Konsep Biologi Kemungkinan Penyebab dan Cara Penanggulangannya. Pidato pengukuhan dibaca pada peresmian penerimaan jabatan guru besar dalam bidang ilmu hayat pada jurusan pendidikan Biologi FPMIPA IKIP Surabaya, tanggal 4 Desember 1997.

Kardi, S. Dkk. 1999. Konsep IPA Terpilih di Sekolah Dasar kesalahan yang Sering Dijumpai dan Saran Penyelesaiannya. DIKDASMEN. (p.1)

Kimball, John W et al. 1988. Biologi(1). Jakarta: PT. Gelora Aksara Pratama.

Kimball, John W et al. 1988. Biologi(2). Jakarta: PT. Gelora Aksara Pratama.

Loveless, A.R.. 1987. Prinsip-Prinsip Biologi Tumbuhan untuk Daerah Tropik (1). Jakarta: P.T Gramedia.

Loveless, A.R.. 1987. Prinsip-Prinsip Biologi Tumbuhan untuk Daerah Tropik (2). Jakarta: P.T Gramedia. 
Moyer, R., Daniel, L., Hackett, J., Baptiste, H.P., Stryker, P., Vasquez, J. 2002. McGraw-Hill Science Grade3. New York: McGraw-Hill. P. B14-B22.

Salisbury, Frank B dan Cleon W Ross. 1995. Fisiologi Tumbuhan (1). Bandung: ITB.

Salisbury, Frank B dan Cleon W Ross. 1995. Fisiologi Tumbuhan (2). Bandung: ITB.

Sumaji, dkk. 2003. Pendidikan Sains yang Humanistis. Yogyakarta: Kanisius.

Tjitrosoepomo, Gembong. 2007. Morfologi Tumbuhan. Yogyakarta: Gadja Mada University Press.

Wulangi. Kartolo S. 1994. Prinsip-Prinsip Fisiologi Hewan. Jakarta: Departemen Pendidikan dan Kebudayaan. 